\title{
Web上の情報を用しけた企業間笑係の抽出 \\ Extracting Inter-business Relationship from World Wide Web
}

\author{
金 英子 \\ 松尾 豊 \\ Yutaka Matsuo \\ 石塚 満 \\ Mitsuru Ishizuka \\ 東京大学大学院 情報理工学系研究科 電子情報学専攻 \\ Graduate School of Information Science and Technology, The University of Tokyo \\ eiko-kin@mi.ci.i.u-tokyo.ac.jp \\ 独立行政法人 産業技術総合研究所 \\ National Institute of Advanced Industrial Science and Technology \\ y.matsuo@aist.go.jp, http://ymatsuo.com/
}

keywords: WWW, social network, information extraction, search query, relation extraction

\section{Summary}

Social relation plays an important role in a real community. Interaction patterns reveal relations among actors (such as persons, groups, companies), which can be merged into valuable information as a network structure. In this paper, we propose a new approach to extract inter-business relationship from the Web. Extraction of relation between a pair of companies is realized by using a search engine and text processing. Since names of companies co-appear coincidentaly on the Web, we propose an advanced algorithm which is characterized by addition of keywords (or we call relation words) to a query. The relation words are obtained from either an annotated corpus or the Web. We show some examples and comprehensive evaluations on our approach.

\section{1.まえがき}

企業間にはさまざまな関係があるが, 企業間の関係が 総体として織り成すネットワーク構造を分析することで， 例えば，ある企業が他の企業と競争関係であるか，どう すればネットワーク上で優位な立場に位置することがで きるかなど，企業の競争力の分析や取るべき戦略の決定 に用いることができる．また，全体的なネットワーク構 造の特徵を分析することで，产の産業分野全体における ネットワークの安定性，成長性も分析することができる . 経济学や社会学の分野では，このようにネットワークを 分析し,関係構造の中に隠された知見を読み解く社会ネッ トワーク分析と呼ばれる研究が行われている [相馬 05 , 安 田 97 , 金光 03$]^{* 1}$.

一方, 近年では多種多樣な情報が Web 上に公開されて いる．個人の Blog から政府の公開情報まで，ますます 多くの新しい情報が Web 上に存在するようになってき ており，Webから有用な知識を抽出しようとする研究が

*1 国際的には, INSNA(International Network for Social Network Analysis: 1978 年に Barry Wellman によって創 設) という団体が，毎年 Sunbelt conference という国際会議 を開いている．また, Social Networks というジャーナルか测 行されている.
盛んに行われている [佐藤 01, 藤井 04, 立石 04] . さらに 最近では, BlogやSNS の分析 [Adar 04, 湯田 05]，ま た研究者ネットワークを抽出する研究 [松尾 05, Matsuo 06b] など，Web 上の情報からネットワーク分析に必要 なデータを抽出し分析する研究が行われている．多樣な データに対して社会ネットワーク分析の手法が適用可能 になっている。

Web 上では企業同士の関係に関わる情報も公開されて いる.企業間の共同開発, 合併・買収, あるいは訴訟など の情報は , プレスリリースや報道などの形で素早く Web 上に公開されることが多い，本研究は，Web 上に公開さ れている情報から，企業間の関係を抽出する手法を提案 する . 日々変化する複雑な社会の関係性を俯瞰すること は, 社会の動向を見渡し, 兴の構造を深く理解して新た な活動につなげる上で重要であり, 社会学や俯瞰工学と いった分野で研究されている [増田 06, 坂田 05].これ まで, Web 上の情報から企業ネットワークを抽出する研 究は行われておらず, 複数の企業の俯政的な情報を得た り, 社会ネットワーク分析の手法を利用した構造的な分 析を行う上で重要な技術である。企業間には，取引，提 携, 役員派遣, 訴訟など樣々な関係があるが, 本研究で は, 特に提携関係と訴訟関係に焦点を当てて, 抽出手法 


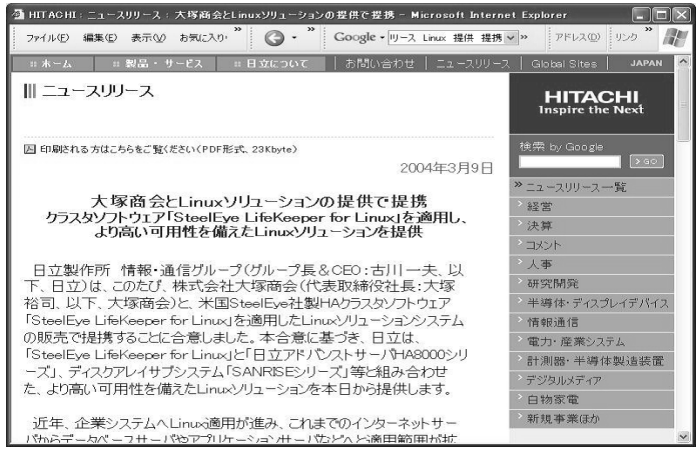

図 1 業務提携に関する報道

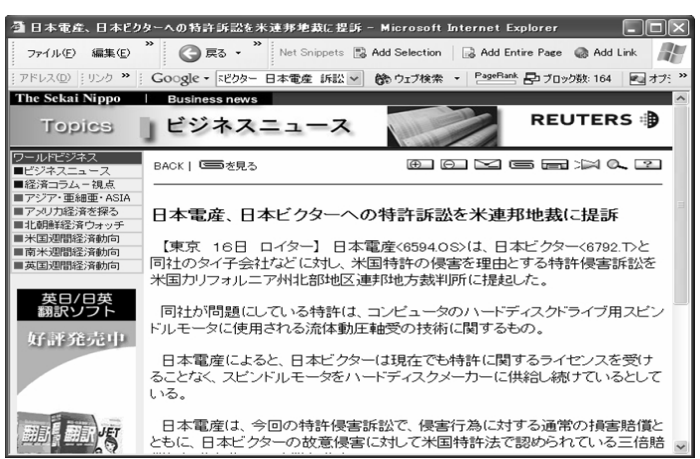

図 2 訴訟に関するニュース

を構築する．

本論文は, 2 章では, Web から企業間の関係を抽出す る概要について説明し , 3 章では, 関係の抽出において 重要な, 関係語を特定する方法について述べる. 4 章と 5 章では, システム全体の流れと実験考察について説明し， 6 章で関連研究との比較を行い，7 章で結論を述べる．

\section{2. 企業間関係の抽出}

\section{$2 \cdot 1$ 検索エンジンを利用した関係抽出}

Web 上には , 企業の関係を表す多くの情報があるが，

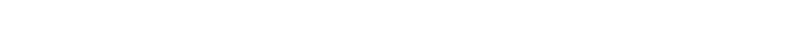
る.ひとつは, 企業間の関係を整理してまとめてあるサイ トで, 例えば，Yahoo!ニュース ${ }^{* 2} や 日$ 経のプレスリリー スサイト*3などである .こういった整形された情報源は Web に限らず, 会社四季報などの書籍からも企業間の関 係について知ることが可能である .

もうひとつは, 企業が自ら公開するニュースリリース や Web 上のニュースサイトなど , 分散した情報源である . 例えば，図１は企業のホームページ上に掲載された業務 提携に関するリリース*4であり，図 2 はビジネスニュー

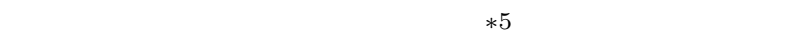
定のサイトに整形されてまとめて置かれているのではな く，さまざまなサイトに分散して存在する .

情報源として考えると，前者の情報は，何らかの編集 作業を経ているため，信頼性が高く，統一的な基準であ るという意味で質が高い，一方，後者の情報は，基準は

*2 http://headlines.yahoo.co.jp/hl

$* 3$ http://release.nikkei.co.jp

*4 http://www.hitachi.co.jp/New/cnews/040309.html

*5 http://www.worldtimes.co.jp/の 2005 年 2 月 16 日の記事
一定でなく，信頼できない情報が含まれているかもしれ ないが , 中小企業や海外の企業などの情報も得られると いう点で網羅性が高く，また新しい情報を弚のまま取り 扱うことも可能である . 今後の Web の発展を考えると， 後者のように整形されていない情報を収集し情報源とす ることは，重要な技術になると考えられる．

弚こで, 本研究では Web 全体の情報を用いて企業間 関係を抽出することを目的とする . 特定の企業名を与え たとき，乥の間の関係をWeb 中の情報から同定する . 光 のために検索エンジンを用いて Web ページを集め，文 書処理を行う.

\section{$2 \cdot 2$ 関係を特定する関係語}

検索エンジンを利用して，2つの企業の関係を調べる ときに考えられるのは, 弚の $2 つ$ 企業名を並べてクエ リとすることであろう . 例えば, 松下電器とジャストシ ステムの関係を調べたいとすると，

「松下 AND ジャストシステム」

と検索エンジンにクエリを投げれば , 425,000 件*6 もヒッ 卜する .上位のページには , 昨年話題になった松下とジャ ストシステムの訴訟に関するページ*7が多く含まれる．し たがって，このテキストを分析すれば，松下とジャスト システムの訴訟関係は同定でき弚うである .

ところが , 松下とジャストシステムは , 実は 2001 年に ナレッジマネジメントにおける提携を行っている．この Web ページ*8は，ヒットした文書中 124 件目であった . このように企業間の関係はさまざまなものがあり，大企 業同士の提携や訴訟関係など，注目される関係は多くの ページに書かれているが, 逆に話題にならなかった関係 は，ごく少数のページにしか情報がないこともある．

ここで, 仮に , 検索クエリを「松下 AND ジャストシ ステム AND 訴訟」，あるいは,「松下 AND ジャスト システム AND 提携」としてみよう．すると，乥れ光れ 松下とジャストシステムの訴訟関係や提携関係に関する ページが上位に来ることになる．これは，キーワードス パイス [Oyama 04] に近いアイディアであり，目的とする ページを上位にヒットさせるために, クエリに適切なキー ワードを加えるものである . 本研究では , このような関係 を特定するためにクエリに加える語を関係語( Relation word）と呼ぶことにする .

関係語は, 対象となる企業間の目的とする関係をうま く特定できる方か望ましく，また，関係がある場合には できるだけ漏れが少なくページを見つけられる方がよい． したがって，関係語を加えることにより，関係を特定す る精度と再現率の両方について考慮する必要がある．こ れについては，3.1 節で詳しく説明する．

*6 2005 年 5 月 22 時点での Google による検索結果，以下の 例でも同樣

*7 http://pc.watch.impress.co.jp/docs/2005/0201/just2.htm

$* 8 \mathrm{http}: / /$ ascii24.com/news/の 2001 年 2 月 19 日の記事 
$2 \cdot 3$ 本研究で取り扱う 関係

企業間の関係としては, 株式の持ち合いや子会社・グ ループ会社といった資本的な関係，業務上での提携関係 や取引関係, 役員等の人的な関係, 訴訟・係争関係, 競 合関係などさまざまなものがある．社会学におけるネッ トワーク分析 [安田 97, 金光 03, Scott 00] では, 企業間 の紐帯 (ネットワーク分析では関係を紐帯と呼ゔ) の種 類や強さ，また兴の成長や淘汰といった時間的変化も重 要な分析材料になる.

例えば，企業間の訴訟を考えると，訴訟関係が永続す るわけではなく，いずれ和解や判決により決着がつく．し たがって，係争中の訴訟関係なのか，和解した訴訟関係 なのかという区別をつけることは重要である . また , 企 業間の提携関係では，製品の共同開発やサービスの共同 提供といった業務提携と，資本参加を含めた合併・買収 や営業譲渡などの資本提携の関係がある．前者よりも後 者の方が強い関係である．

本研究では，企業間の関係として，提携関係と訴訟関 係を扱う. 光れ光れ，企業間の友好的関係，敵対的関係 の代表的なものである.さらに，提携関係は，業務提携 と資本提携，訴訟関係は係争関係と和解関係という 4 種 類を扱うことにする．提携関係に対しての業務提携や資 本提携の関係，また訴訟関係に対しての係争関係や和解 関係を，詳細関係と呼ぶことにする．

\section{3. 関係語の抽出}

本章では, 求めたい企業間関係が記述されたページを 見つけるために，検索クエリに加える関係語を得る方法 について述べる．学習データを用いる方法と，Web の共 起を用いる方法を提案する .

\section{$3 \cdot 1$ 学習データからの関係語の獲得}

関係語を得るためには，企業間の関係が含まれた多く の Web ページを準備して，光のページに共通する語を 求めればよい，つまり，学習データから特定性の高い関 係語を学習する .

まず，業務提携や資本提携などの企業間関係について 書かれた Web ページと，乥うでないページを集め学習 データを作る . 各 Web ページから語が出現するかしな いかという属性を生成し, 分類を学習する.

本来は, 語の出現を含むぺージのさまざまな特徵を属 性とする分類問題になるが, 現実的には, 検索エンジン に複雑なクエリを入力するのは難しいため ${ }^{*}$, 単語 1 語 , もしくは光のうち 2 語の連言による組み合わせだけを調 べる．学習の評価に F 尺度を用いることにすると，この 分類問題は, 各単語 (もしくは午の組み合わせ) が出現

$* 9$ 検索エンジンによっては, クエリ内の単語の数が制限されて いたり，NOTや OR のオペレータが必ずしも正確な結果を返 さない場合がある。
するかどうかによって F 尺度がどう変化するかを調べれ ばよいことになる．

関係が含まれたページを正解，ある語 $w$ が含まれてい るページを出力として , F 尺度は

$$
\mathbf{F}_{R e l}(w)=\frac{2 \mathbf{P}_{R e l}(w) \mathbf{R}_{R e l}(w)}{\mathbf{P}_{\text {Rel }}(w)+\mathbf{R}_{\text {Rel }}(w)}
$$

と定義される. $\mathbf{P}_{R e l}(w)$ は, 単語 $w$ を含むぺージのうち 関係が正しく記述されたページの割合であり， $\mathbf{R}_{R e l}(w)$ は，関係が記述されたページのうち単語 $w$ が含まれる ページの割合である，一般的に, 学習データに対して最 も分類精度のよい仮説を選ぶと過学習が起こる可能性が あるが，ここでは関係語として単語1語もしくは2 2 語に 限定しているので, 乥の影響は少ない。

$\mathrm{F}$ 值が高い語を関係語として用いると，企業関係につ いて書かれたページが得られる可能性が高くなるが，確 実に得られるわけではない . 複数の関係語を用いて , 検 索クエリを複数生成し検索することで，より網羅的に関 係を抽出することができる．したがって， F 值が上位の 複数の関係語を用いる．また，検索されたテキストの内 容から企業間関係か実際に存在するかを判断するルール の中でも，この関係語を利用する．

\section{$3 \cdot 2$ Web 用いた関係語の抽出}

一方，関係語を得るために学習データを用意するのは 手間がかかる. 弚こで, 本研究では, Web を用いて関係 語を抽出することを考える.この方法は [森 05a] と同樣 の方法であり，関係を特定する単語が与えられたときに， 乥れに関連する他の語を得ることができる．また，少数 の学習データが与えられたときに, 乥こから多くの関係 語を得ることも可能である。

基本的なアイディアは，例えば提携関係を調べたいの であれば，「提携」という語を直接クエリに加えればよい というものである.さらに「提携」とよく共起する語も， 提携関係を把握する手がかになり光うである．弚こで， 「提携」という語とよく共起する語を Web 上から獲得し ようというものである .

ここでは，「提携」などの語を $w_{R e l}$ とする. 乥して， Web 上でのヒット件数を用いて Jaccard 係数

$$
J_{w_{R e l}}(w)=\frac{\left|w_{R e l} \cap w\right|}{\left|w_{R e l} \cup w\right|}
$$

を計算し，これが高い語 $w$ を関係語として用いる。ただ

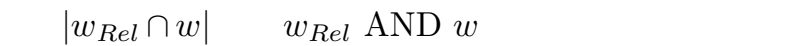
のヒット件数， $\left|w_{R e l} \cup w\right|$ は「 $\left\ulcorner w_{R e l} \mathrm{OR} w\right\lrcorner$ をエリに した場合のヒット件数である.

なお，全ての語に対してこの值を計算するのは現実的 でないので,ここでは企業間関係について書かれたペー ジを用意し，乥こから候補をとなる単語を切り出す。例 えば，提携関係であれば，日経のプレスリリースカテゴ リから取得する．しかし，学習データを使う方法と違っ 


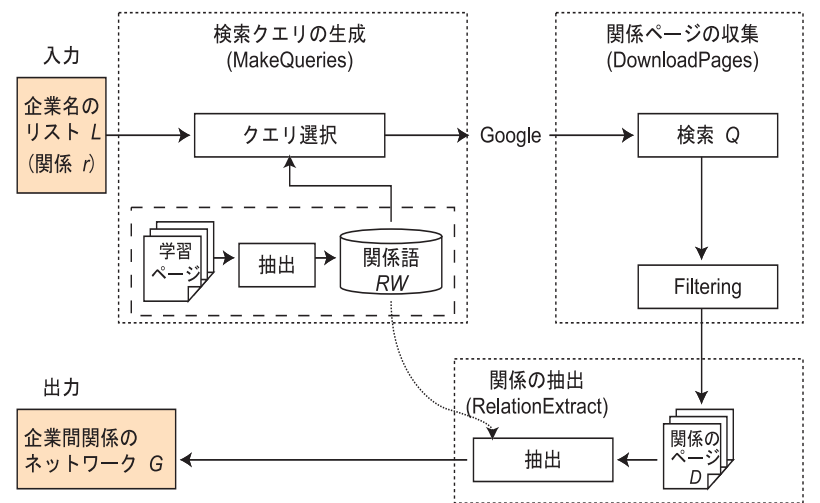

図 3 システム全体の流れ

て，各ページごとに実際に提携関係について記述されて いるかというラベルを付与する必要はない .

企業間の詳細関係を得るために，詳細関係に応じた関 係語を取得する必要がある．この場合も，上に述べた学 習データによる方法, Webから取得する方法のいずれを 用いることもできる．

\section{4. システム全体の流れ}

システムの全体を図 3 に示す. 具体的な処理の流れは 図 4 の擬似コードとして記述する.前節に述べた方法で， あらかじめ提携関係，訴訟関係などの関係ごとに関係語 $R W$ のリストを取得しておく . 乥して , システムに企業

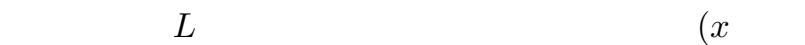
る) を取り出し, 自分以外の企業 ( $y$ とする) との関係 $r$ の有無を調べてエッジを生成することで, 企業間の関係 のネットワーク $G$ を出力する . 全体の処理は , 検索クエ リの生成, 関係ページの収集, 関係の抽出という大きく 3つに分けられる。

検索クェリの生成フェーズ (MakeQueries) では, 関 係語の上位 $n_{\text {queries }}$ 個を氏名 $x, y$ に加えることで検索 クェリ集合 $Q$ を生成する . 関係ページの収集フェーズ (DownloadPages) では,生成された検索クエリ集合 $Q$ を検索エンジンに入力し，上位にヒットしたページ $n_{\text {pages }}$ 件をダウンロードして関係のページ集合 $D$ を得る . 最後 の関係の抽出フェーズ (RelationExtract) では, ダウ ンロードしたページの内容を調べ，2つの企業に関する 関係の記述があるかどうかを判断する .

（1）収集した関係ぺージ集合 $D$ に含まれる全ての文の リスト $S$ を収集する

(2) 2つの企業の名前と関係語 $r w(r w \in R W)$ が同時 に出現する文 $s(s \in S)$ に対して,$s$ に出現する関係 語のスコアを足し合わせて兴の文のスコア score $_{s}$ と し，すべての文の中で最もスコアの高いものを㫕の 企業間関係のスコア score $_{x y}$ とする .

(3) score $_{x y}$ が閾値 score $_{\text {thre }}$ を超えれば，2つの企 業は関係があると判断する .この部分は，構文解析 や意味解析などより深い処理を行うことも可能であ

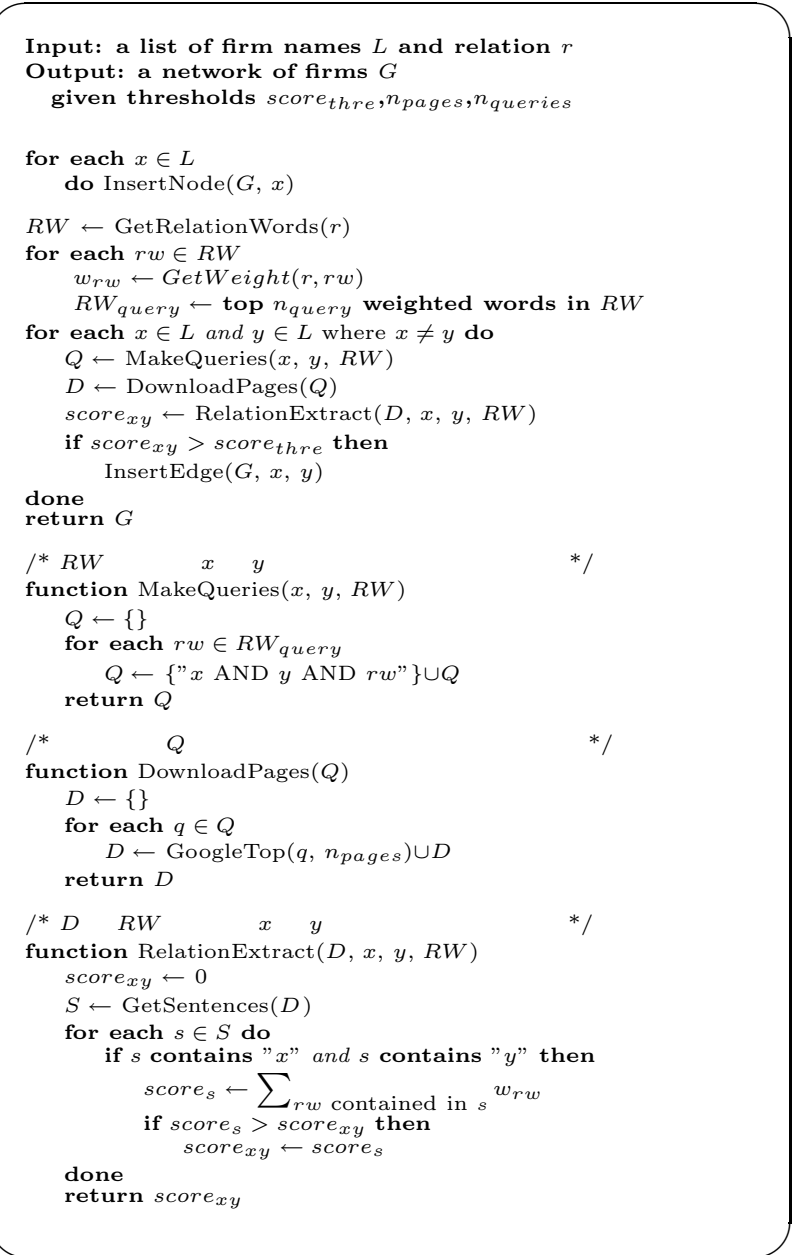

•InsertNode $(G, x)$ : ノード $x$ をネットワーク $G$ に追加する

-InsertEdge $(G, x, y): x$ と $y$ をつなぐエッジをネットワーク $G$ に追加する

- GetWeight $(r, r w)$ : 関係 $r$ に対する関係語 $r w$ の重みを返す

- GetRelationWords $(r)$ : 3.1 節と 3.2 節の手法から得られる関係 $r$ の関係語の 集合を返す．

- GoogleTop $\left(q, n_{\text {pages }}\right)$ ：クエリ $q$ で検索してヒットする上位 $n_{\text {pages }}$ 件のペー ジ集合を返す

•GetSentences $(D)$ : 関係のページ集合 $D$ に含まれる全ての文をリストで返す

図 4 システム全体の擬似コード

るが, 本研究ではできるだけ簡単な方法にするため, このようなシンプルなルールを用いている．本研究 では, $n_{\text {queries }}=2, n_{\text {pages }}=5$ とした 。

なお，閾値 score $_{t h r e}$ は，予備実験において企業の関 係の有無を判断しておいた学習データから F 尺度が最大 になるような值にしている*10. 閾値を高くすると，特定 性の高い関係語を多く含むような記事でない限り2つの 企業は関係がないと判断されてしまうので再現率が下が る．逆に，閾値を低く設定すると，特定性の低い語を含 んで実際に関係がない企業に対しても関係があると判断 されることが多くなるので適合率が下がる .

*10 学習データから獲得した関係語を用いる場合，提携関係と 兴の詳細関係である業務提携と資本提携の閾値は，兰れ光れ 1.1984, 3,3429, 0.6598 である. Web を用いて抽出した関係

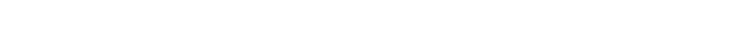
$0.5044,0.8786,0.2575$ で, 訴訟関係と产の詳細関係である係

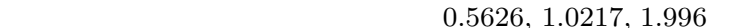
ある 
表 1 用いた企業名

松下電器産業, ジャストシステム, ニッポン放送，ライブドア， 日本電産株式会社, 目本ビクター株式会社, 目本 IBM , キヤノ ンスター, 株式会社ニデック, 株式会社カイノス, 東和薬品, 三 井住友カード, 東京電力, エレコム, フジテレビ, 富士通株式会 社，富士通インフォソフトテクノロジ，コネクトテクノロジーズ， バイオマティクス, サムスン SDI , イーバンク銀行, 株式会社 ニコン，A S M L 社，日本マックストア，ミネベア株式会社，株 式会社東芝, 韓国ハイニックス, 米 SCO, 米 IBM , 株式会社卜 ランスウエア, Opera Software, 米 Agere, 米 Intersil , 米イン テル, 米ブロードコム, LG 電子株式会社, セイコーエプソン, 上海中材 , シスコシステムズ , サン・マイクロシステムズ・イン ク, 日本電気株式会社, KDDI 株式会社, 日立製作所, ソースネ クスト株式会社 , 東京エレクトロン株式会社 , ルネサステクノ ロジ, シックス・アパート, ニイウス株式会社, 楽天株式会社, サイバーブレインズ, 全日本空輸, ニフティ株式会社, 松下電子 工業，京セラ株式会社，株式会社サイバード，株式会社 JIMOS， 日本セラテック，セランクス，日本信販株式会社，株式会社 UFJ カード

\section{5. 評価実験と 考察}

この章では，本論文で提案した手法の評価を行う．ま ず，抽出された企業間関係の具体例を示し，企業間の関 係をどの程度的確に抽出できるかというシステム全体の 評価を行う，弚の後，関係語取得に関する部分の具体例 と評価を行う.

情報，通信，放送，電機などの産業分野を中心に 60 社 を選び，弚の企業間関係をWeb から抽出した . 具体的 に用いた企業名を表 1 に示す . 大企業から情報系の新し い企業まで幅広く含んでいる。

\section{$5 \cdot 1$ 企業間関係抽出の具体例と 評価}

4 章に述べた方法で, 関係の有無を判断する．つまり 60 社の組み合わせ，つまり ${ }_{60} C_{2}$ の 1770 通りに対して，

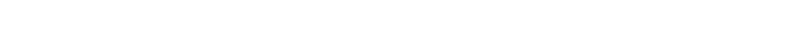
率および再現率の評価を表 2 に示す．表 $2(\mathrm{a})$ は，3.1 節 で提案している学習データから獲得した関係語を利用し て抽出した提携関係 (および光の詳細関係) の結果であ る. 1770 組の企業間に実際には提携関係が 113 組存在 するが，本手法では 68 組抽出することができた . また 提携関係の詳細関係である資本提携と業務提携は実際 21 組と 100 組存在することに対し，本手法では光れ攵れ 11 組と 58 組を抽出することができた . なお，正解データ

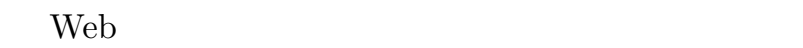
とで作成している．Webに書かれていない外部知識は利 用しないため，原理的には $100 \%$ の適合率，再現率を取 りえる. (b) と (c) は， 3.2 節で提案しているWeb を用い て抽出した関係語を利用して抽出した提携関係と訴訟関 係の結果である，光れ光れの実験で検索クエリに利用し た関係語は，表 5 ，表 6 と表 7 の各関係においての上位 2 語である.学習データから獲得した関係語を利用した 結果と Web を用いて抽出した関係語を利用した結果を 比較すると, 再現率はほぼ差がないが, 前者のほうの適
表 2 本手法により抽出された関係の評価

(a) 学習データから得られた関係語を利用 (提携関係)

\begin{tabular}{c|ll}
\hline 関係・詳細関係 & 適合率 & 再現率 \\
\hline 提携関係 & $55.7 \%(68 / 122)$ & $60.2 \%(68 / 113)$ \\
資本提携 & $23.9 \%(11 / 46)$ & $52.4 \%(11 / 21)$ \\
業務提携 & $55.2 \%(58 / 105)$ & $58.0 \%(58 / 100)$
\end{tabular}

(b) Web の共起関係から得られた関係語を利用 (提携関係)

\begin{tabular}{c|ll}
\hline 関係・詳細関係 & 適合率 & 再現率 \\
\hline 提携関係 & $60.9 \%(70 / 115)$ & $62.0 \%(70 / 113)$ \\
資本提携 & $75.0 \%(9 / 12)$ & $42.9 \%(9 / 21)$ \\
業務提携 & $67.4 \%(60 / 89)$ & $60.0 \%(60 / 100)$ \\
\hline
\end{tabular}

(c) Web の共起関係から得られた関係語を利用 (訴訟関係)

\begin{tabular}{c|ll}
\hline 関係・詳細関係 & 適合率 & 再現率 \\
\hline 訴訟関係 & $61.5 \%(16 / 26)$ & $100 \%(16 / 16)$ \\
係争段階 & $63.6 \%(14 / 22)$ & $87.5 \%(14 / 16)$ \\
和解段階 & $72.7 \%(8 / 11)$ & $88.9 \%(8 / 9)$ \\
\hline
\end{tabular}

表 3 Web サイトに含まれている関係の評価

\begin{tabular}{c|ll}
\hline 関係・詳細関係 & 適合率 & 再現率 \\
\hline 提携関係 & $100.0 \%(27 / 27)$ & $23.8 \%(27 / 113)$ \\
資本提携 & $100.0 \%(6 / 6)$ & $28.6 \%(6 / 21)$ \\
業務提携 & $100.0 \%(21 / 21)$ & $21.0 \%(21 / 100)$ \\
\hline 訴訟関係 & $100.0 \%(11 / 11)$ & $68.8 \%(11 / 16)$ \\
係争段階 & $100.0 \%(11 / 11)$ & $68.8 \%(11 / 16)$ \\
和解段階 & $100.0 \%(6 / 6)$ & $66.7 \%(6 / 9)$ \\
\hline
\end{tabular}

合率が低いことが分かる.これは, 学習データから獲得 した関係語のスコアは学習データに偏った表現が多いの で関係 (特に詳細関係) を正確に特定できないことであ る.なかでも資本提携の精度が低くなっているのは, 学 習データにおいて「提携」「合意」「提供」といった業務 提携を特定するスコアが高い関係語が，資本提携におい ても高いスコアを持っているので , 関係の抽出段階で実 際には業務提携であるのに資本提携と誤って判断される ことが多いことが原因であった．また，訴訟関係と光の 詳細関係は，提携関係よりも正確に抽出することができ た。これは,訴訟関係は「提訴」「判決」「訴訟」「和解」 といったある程度決まった用語を使うことが多いことに 対し，提携関係は，サービス提供や共同研究，販売提携， 合併・買収などに関する多樣な表現が用いられるので , 再 現率が低くなっている。

なお，現実的に Web 上の情報から企業間関係を取得 することを考えた場合，特定の Web サイトにまとめて いる情報を利用することができる．乥こで，手法自体の 比較対象ではないが，提携関係は日経のプレスリリース サイトから，訴訟関係は知的財産局の訴訟ニュースから， この 60 社の関係を調べたものが表 3 である . これらのサ イトは，もちろん適合率は $100 \%$ であるが，例えば，日 経のプレスリリースでは半年間のニュースしか公開しな いし，知財局のサイトでも最大 2,008 件のニュースだけ を検索対象にするなど，情報の期間が限定されたり，情 報の量を制限したりしているので，すべての企業の情報 
表 4 関係の抽出の例

\begin{tabular}{|c|c|c|c|c|c|c|}
\hline 企業名ペア & \multicolumn{2}{|c|}{\begin{tabular}{l|l}
\multicolumn{2}{c}{ 正解 } \\
轭
\end{tabular}} & \multicolumn{2}{|c|}{\begin{tabular}{l|l}
\multicolumn{2}{|c|}{ web site } \\
訕 & 㕲 \\
\end{tabular}} & \multicolumn{2}{|c|}{\begin{tabular}{l}
\multicolumn{2}{l}{ 本手法 } \\
訴 \\
\end{tabular}} \\
\hline 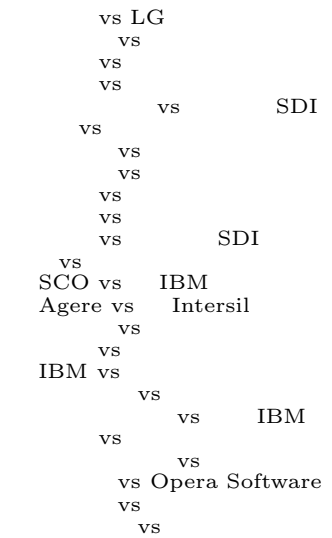 & $\begin{array}{l}8 \\
0 \\
0 \\
0 \\
0 \\
0 \\
0 \\
0 \\
0 \\
0 \\
0 \\
0 \\
0 \\
0 \\
0 \\
0 \\
0 \\
- \\
- \\
- \\
- \\
- \\
- \\
- \\
-\end{array}$ & $\begin{array}{l}0 \\
O \\
O \\
O \\
0 \\
0 \\
0 \\
0 \\
O \\
O \\
- \\
- \\
- \\
- \\
- \\
- \\
- \\
- \\
- \\
- \\
- \\
- \\
-\end{array}$ & $\begin{array}{l}0 \\
0 \\
0 \\
0 \\
0 \\
0 \\
- \\
- \\
- \\
0 \\
0 \\
0 \\
0 \\
- \\
- \\
0 \\
- \\
- \\
- \\
- \\
- \\
- \\
- \\
-\end{array}$ & $\begin{array}{l}0 \\
\bigcirc \\
\bigcirc \\
\bigcirc \\
0 \\
0 \\
- \\
- \\
- \\
- \\
- \\
- \\
- \\
- \\
- \\
- \\
- \\
- \\
- \\
- \\
- \\
- \\
-\end{array}$ & $\begin{array}{l}0 \\
0 \\
0 \\
0 \\
- \\
0 \\
0 \\
- \\
0 \\
0 \\
0 \\
0 \\
0 \\
0 \\
0 \\
0 \\
0 \\
0 \\
0 \\
0 \\
0 \\
0 \\
0 \\
0\end{array}$ & 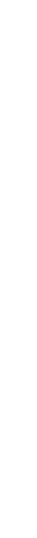 \\
\hline
\end{tabular}

を網羅できないことから，再現性は低い，

表 4 は, 訴訟関係の詳細関係である提訴段階と和解段 階について，本システムで実際に抽出した具体例と正解， および日経/知財局の Web サイトに含まれている記事の 具体例を示したものである 「○」は関係があることを表 し「ー」は関係がないことを表す．例えば「エレコム」と 「エプソン」の間には, 訴訟関係があって, 光れが提訴段 階から和解段階に至っているのが正確な関係だが, これ は 2000 年と 2002 年の古いニュースであることから，知 財局のサイトには載っていないが, 提案手法ではこの関 係を抽出することができる.しかし，実際にない関係も あると出力される場合がある . 例えば，表 4 に示されて いる日立製作所と米 IBM の間の実際に存在しない訴訟関 係が抽出された .これは “日立製作所と米 IBM の HDD 合弁会社、特許侵害で中国企業を提訴” という文が原因 で, 実際には中国企業との係争であることを示す文であ るが, 文内に複数の企業名 (「日立制作所」「米 IBM」「中 国企業」) と複数の関係語（「特許」「侵害」「提訴」「会 社」「企業」)を含んでいるために誤ったものである．こ れは適切な係り受けの解析を行うことで対処できると考 えられ，4.3 節で述べた関係の抽出フェーズを改良する ことでさらに精度が改善される可能性がある．また，実 際に関係があるが抽出できなかった場合として，特定性 の高い関係語が記事の中に出現しないケースがある.例 えば,「ライブドア vs イーバンク銀行」では，提携関係 を行おうとしたあとトラブルが起き，イーバンクがライ ブドア社長を刑事公訴し，すぐに訴訟を取り上げて和解 となった . 厳密には訴訟関係があったのだが, 記事中で は「騒動」や「トラブル」と表現され, うまく取り出す ことができなかった . 抽出したい関係を詳細化し「公訴」 といった語が使われる場合もあることをシステムは認識 する必要がある.こういった係り受け解析と関係の詳細 化が今後の課題のひとつである .

图 5 は, 企業名をノードとし, 抽出された関係 ${ }^{* 11}$ をリ

*11 ここでは, Web を用いて抽出した関係語を利用して抽出し
ンクで繁ぐことで訴訟関係と提携関係のネットワークを 生成したものである．黑線が提携関係を示し，点線か訴 訟関係を示す.点線のなかでも太線は資本提携を，光う でないものは業務提携である.また, 点線で, 破線は係争 段階を表し，細い点線は和解段階を表す．ネットワーク 図からは, 電機・電力の大手企業を中心に連携が活発に行 われていることが分かる.特に，活発に周りと連携して いる松下や日立，積極的に合併・買収などに取り組んでい るライブドアといった姿を理解することができる．また， 社会ネットワークの分析手法を適応することで, 他企業 と似たような紐帯 (関係) を持っている企業同士*12や， 企業間の連携において媒介的な役割をする企業, さらに ネットワーク全体の密度や傾向などを分析することが可 能である .

\section{$5 \cdot 2$ 関係語抽出の具体例と考察}

本研究では, 最終的な企業間の関係を抽出するために， 関係語をいかに得るかが重要な部分であるが，本節では 光の具体例を示す．

3.1 節で述べた，学習データを作り $\mathrm{F}$ 尺度の高い関係 語を示したものが表 5 である。提携関係について，F 尺 度が高いものは「事業 AND リリース」「ニュース AND 事業」などであった．また，提携関係の中でも，資本提

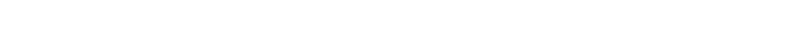
れ「通信 AND 合意」「合意」，「提携 AND 今回」,「提 携 AND 提供」などが上位であった .

この結果を考察すると,「リリース」「ニュース」などの 語は情報源を特定する働きが強く、事業」「開始」など は具体的な提携関係を示す語である .この組み合わせで ある「事業 AND リリース」や「ニュース AND 事業」 は，情報源を特定しながら提携関係を把握するよい関係 語である．しかし 5 位の「発表」や 9 位の「リリース」 などの関係語は，提携関係を示す具体的な語が入ってお らず，この学習データに偏った結果であると考えられる． 詳細関係に対しては,さらにこの傾向か強い，

つぎに，3.2節で述べた，Webを用いた関係語の取得 について具体例を示す . 提携関係に関しては $w_{R e l}$ を「提 携 AND 株式会社」(与えた企業名はすべて株式会社で あるため), 訴訟関係に関しては「侵害 AND 訴訟」と

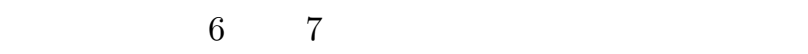
訟関係，および光れらの詳細関係に対して，Jaccard 係 数が高い上位 10 個の関係語と光のスコアを示している. 提携関係の業務提携関係においては「提携 AND 企業」, 「提携 AND 事業」などの語がスコアが高いことに対し， 資本提携においては, 「資本 AND 経営」,「資本 AND 企 業」などの語のスコアが高い，また，訴訟関係の係争段 階においては「特許 AND 提訴」「提訴 AND 技術」の

た提携関係と訴訟関係 $($ 表 2 の (b) と (c)) を用いている *12 ネットワーク分析では構造同值と呼び, このような企業同士 は競争関係になりやすい 


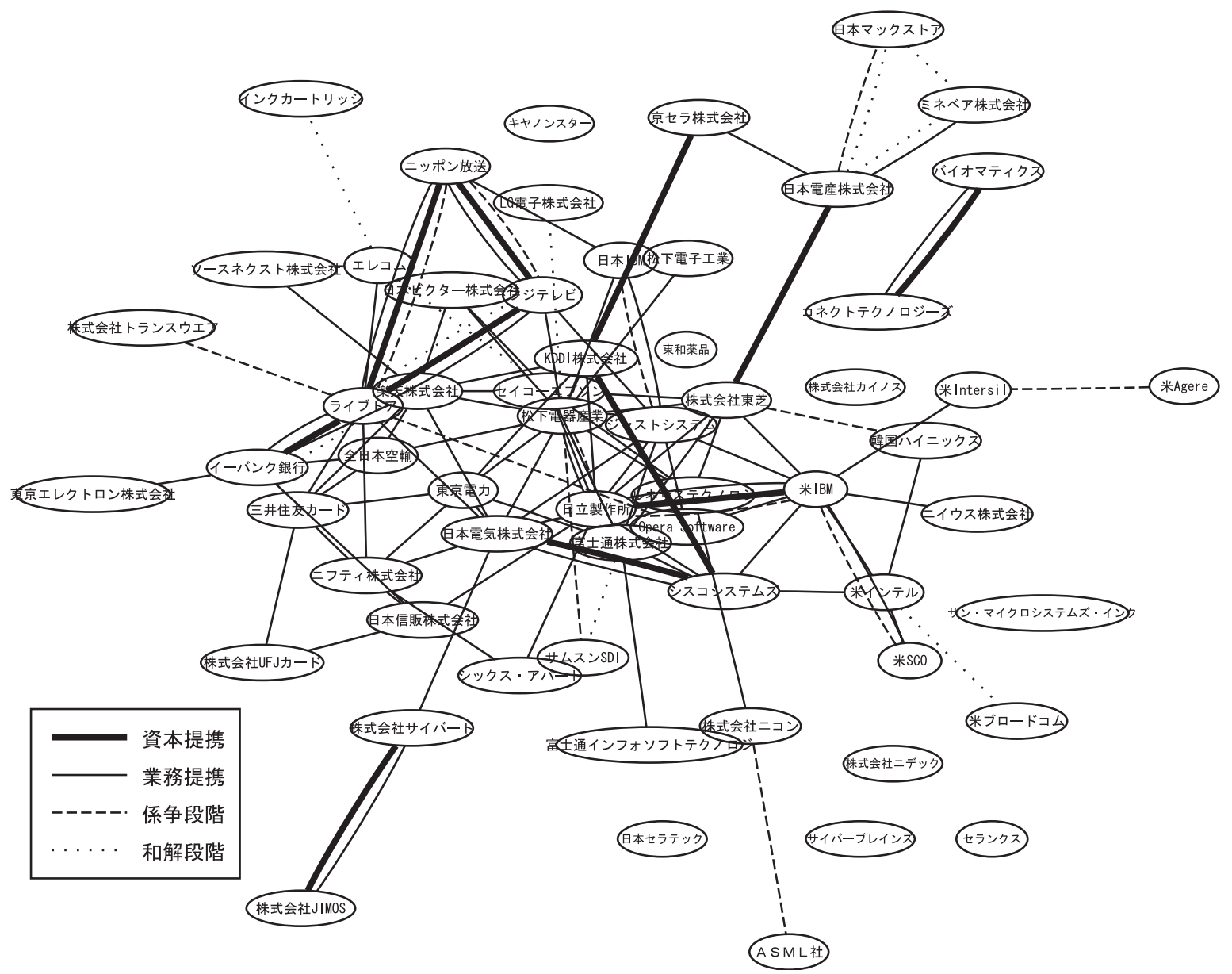

図 5 企業間関係のネットワークの抽出例

ような語がスコアが高いことに対し，和解段階において は「和解 AND 会社」「和解 AND 発表」のような語の スコアが高い，Web 全体においての語の共起を用いてい るので, 学習データを用いる場合よりもロバストで納得 性の高い結果が得られていることが見て取れる .

\section{$5 \cdot 3$ 関係語付与による関係抽出の評価}

最後に，関係語が，企業の関係を示すぺージを探すこ とに対してどのくらい有効であるかを評価する .ここで は, 表 4 で正解として示した 16 組の訴訟関係のペア (关 のうち，8組か既に和解になっている) を取り上げる.単 純に企業の名前のペアをクエリにして検索した場合と， 弚れに関係語を加えて検索した場合で，上位にヒットす るぺージでどのくらい企業間関係の情報を含んでいるか を比較した

ここでは, 次の 5 つを比較している．

noRW 関係語を全く用いない。

RW1 関係語の上位 1 位だけ用いる。

RW2 関係語の上位 2 位だけ用いる.

RW1+ RW2 関係語の上位 1 位と 2 位を用い, 2 回 検索する .

$\mathbf{R W} 1+\mathbf{R W} 2+\mathbf{n o R W}$ 上位 1 位, 2 位，関係語を用 いない場合の 3 回検索する .
複数回検索する場合も，取得するページ数は合計で 10 ページになるようにしている.図 6 に光の結果を示す.適 合率は, 検索結果の上位 $k$ 位中，どれだけのページが光 の企業間の訴訟関係について書かれているか (16 組につ (て平均) を示したものであり，横軸は $k$ である.$k$ を大 きくしていくと，さまざまなほかの情報も含まれるよう になるので, 徐々に適合率は下がる . カバレージは, 検 索結果の上位 $k$ 位中, 光の訴訟関係が含まれれば 1 , 光 うでなければ 0 として，16 組について平均をとったもの である . $k$ が大きくなれば 1 に近くなる .

このグラフで分かるのは, 複数個の関係語で複数回の 検索を行った方が, 1 個の関係語あるいは関係語を入れ ない場合よりページの適合率が高いことである．また， 抽出する関係によっては（特に注目される訴訟関係など は）関係語を加えない場合にもカバレージは高いことが 分かった。

\section{6. 議論と 関連研究}

$6 \cdot 1 \quad \mathrm{~F} \quad$ 尺 度

3.2 節で定義している Jaccard 係数の式は，ある近似 のもとで $\mathrm{F}$ 尺度を最大化する語を見つけていることにな る.まず, 語 $w$ の適合率は, ページに関係か記述されて 


\begin{tabular}{|c|c|c|c|c|c|}
\hline 提携関係 & $F_{\text {提携 }}$ & 業務提携 & $F_{\text {業務提撨 }}$ & 資本提携 & $F_{\text {資本提携 }}$ \\
\hline 事業 AND リリース & 0.4688 & 通信 AND 合意 & 0.4490 & 提携 AND 今回 & 0.4444 \\
\hline ニュース AND 事業 & 0.4522 & 合意 ～～～～～～ & 0.4483 & 提携 AND 提供 & 0.4364 \\
\hline 事業 AND 発表 & 0.4279 & グループ AND 合意 & 0.4243 & 提供 AND 株式 & 0.4333 \\
\hline 事業 AND 開始 & 0.4274 & 事業 AND 合意 & 0.4151 & 事業 AND 株式 & 0.4211 \\
\hline 発表 & 0.4271 & 株式会社 AND 合意 & 0.3956 & 合併 AND 予定 & 0.4071 \\
\hline 事業 AND 記事 & 0.4242 & 合意 AND 目指す & 0.3956 & 合併 AND 合意 & 0.4043 \\
\hline 提携 $\mathrm{AND}$ 提供 & 0.4242 & 記事 AND 合意 & 0.3953 & 株式 AND リリース & 0.4040 \\
\hline 事業 AND 提供 & 0.4228 & 発表 AND 合意 & 0.3918 & 携帯 AND 譲渡 & 0.4000 \\
\hline リリース & 0.4224 & 提携 AND 合意 & 0.3871 & 株式 AND 今回 & 0.4000 \\
\hline 記事 & 0.4224 & 合併 AND 合意 & 0.3863 & 提携 & 0.3979 \\
\hline
\end{tabular}

\begin{tabular}{|c|c|c|c|c|c|}
\hline 提携関係 & $J_{W_{\text {提携 }}}$ & 業務提携 & $J_{W_{\text {業務提㨦 }}}$ & 資本提携 & $J_{W_{\text {瓷本掉推 }}}$ \\
\hline 提携 AND 株式会社 & 1.0000 & 提携 AND 業務 & 1.0000 & 事業 AND 資本 & 1.0000 \\
\hline 提携 AND 株式 & 0.8776 & 提携 AND 企業 & 0.4747 & 資本 AND 経営 & 0.5528 \\
\hline 提携 AND 会社 & 0.7036 & 提携 AND 事業 & 0.4588 & 資本 AND 企業 & 0.5483 \\
\hline 提携 AND システム & 0.5654 & 提携 AND 開発 & 0.4367 & 資本 & 0.5431 \\
\hline 提携 AND ビジネス & 0.5339 & 提携 AND 会社 & 0.4315 & 資本 AND 管理 & 0.5331 \\
\hline 提携 AND サービス & 0.5329 & 提携 AND 提供 & 0.4292 & 開発 AND 資本 & 0.5193 \\
\hline 提携 AND 事業 & 0.5255 & 提携 AND 経営 & 0.4238 & 資本 AND 利用 & 0.5100 \\
\hline 提携 AND 管理 & 0.5200 & 提携 AND 株式 & 0.4190 & 業務 AND 資本 & 0.5058 \\
\hline 提携 AND 開始 & 0.5183 & 提携 AND サービス & 0.4092 & 販売 AND 資本 & 0.5049 \\
\hline 提携 AND 対応 & 0.5071 & 提携 AND 販売 & 0.4089 & 資本 AND 会社 & 0.4940 \\
\hline
\end{tabular}

\begin{tabular}{|c|c|c|c|c|c|}
\hline 訴訟関係 & $J_{W_{\text {挀訟 }}}^{\text {表 }}$ & $\begin{array}{l}\text { Web の共起関 } \\
\text { 係争段階 }\end{array}$ & $\begin{array}{r}\text { 派訟関係 } \sigma \\
J_{W_{\text {係争段階 }}}\end{array}$ & $\begin{array}{l}\text { 係語 } \\
\text { 和解段階 }\end{array}$ & $J_{W_{\text {和解段階 }}}$ \\
\hline 侵害 AND 訴訟 & 1.0000 & 侵害 AND 提訴 & 1.0000 & 訴訟 AND 和解 & 1.0000 \\
\hline 侵害 AND 請求 & 0.5142 & 特許 AND 提訴 & 0.5332 & 和解 AND 会社 & 0.6479 \\
\hline 侵害 AND 判決 & 0.4900 & 提訴 AND 技術 & 0.4860 & 和解 AND 発表 & 0.6456 \\
\hline 侵害 AND 裁判所 & 0.4582 & 提訴 AND 開発 & 0.4825 & 和解 AND 開発 & 0.6410 \\
\hline 侵害 AND 賠償 & 0.4441 & 提訴 AND 関連 & 0.4685 & 和解 AND 製品 & 0.6404 \\
\hline 侵害 AND 会社 & 0.4335 & 提訴 AND 会社 & 0.4639 & 和解 AND 関連 & 0.6290 \\
\hline 侵害 AND 発表 & 0.4267 & 提訴 AND 販売 & 0.4627 & 和解 AND 技術 & 0.6165 \\
\hline 侵害 AND 損害 & 0.4251 & 提訴 AND 企業 & 0.4562 & 和解 AND 情報 & 0.5989 \\
\hline 侵害 AND 企業 & 0.4183 & 提訴 AND 発表 & 0.4528 & 和解 AND 問題 & 0.5843 \\
\hline 侵害 AND 裁判 & 0.4181 & 提訴 $\mathrm{AND}$ 情報 & 0.4448 & 和解 AND 企業 & 0.5799 \\
\hline
\end{tabular}

いることを Rel という記号で表すと，簡略的に次のよう に表される。

$$
\mathbf{P}_{R e l}(w)=P(\operatorname{Rel} \mid w)
$$

つまり, 語 $w$ が出現するページのうちで, 関係か記述さ れている割合である．また，再現率は

$$
\begin{aligned}
\mathbf{R}_{\text {Rel }}(w) & =P(w \mid \operatorname{Rel}) \\
& =\frac{P(\operatorname{Rel}, w)}{P(\operatorname{Rel})}=\frac{P(\operatorname{Rel} \mid w) P(w)}{P(\operatorname{Rel})}
\end{aligned}
$$

となる.ここで, $w_{R e l}$ を関係 Rel を最も適切に表す語

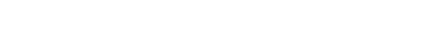

$$
\begin{aligned}
& \mathbf{P}_{\text {Rel }}(w) \sim \frac{\left|w_{\text {Rel }} \cap w\right|}{|w|} \\
& \mathbf{R}_{\text {Rel }}(w) \sim \frac{\left|w_{\text {Rel }} \cap w\right|}{\left|w_{\text {Rel }}\right|}
\end{aligned}
$$

となり，最終的に

$$
\mathbf{F}_{\text {Rel }}(w) \sim \frac{2\left|w_{R e l} \cap w\right|}{|w|+\left|w_{R e l}\right|}
$$

となる.ここで， $|w|+\left|w_{\text {Rel }}\right| \sim\left|w \cup w_{\text {Rel }}\right|$ のとき (通 常, $\left|w \cap w_{\text {Rel }}\right| \ll \max \left(|w|,\left|w_{R e l}\right|\right)$ であるのでこれが成
り立つ)，Jaccard 係数が最大の語を求めることは, $w_{R e l}$ が出現する文書を正解としたときの F 值が最大の語を求 めていることになる .

[森 05a] の研究では, このような文脈を特定する単語 を「コンテキストワード」と呼んでいる．例えば，ある 人物の人工知能に関連する活動を知りたい場合，コンテ キストワードを「人工知能」とし，氏名と共にクェリに 加えることで, 検索されたページから光の人の人工知能 に関連した語を抽出している. 表 6 や表 7 の結果からも 分かるように, 単なる「訴訟」, あるいは「提携」のよう な1語より，2つ以上の単語のペアが関係語として特定 性が高く, Web 上でクェリとして相応しいことがわかる .

\section{$6 \cdot 2 \mathrm{Web}$ 上から企業間関係を抽出する可能性と限界}

企業の関係で重要なものには, 本論文で取り上げた提 携関係や訴訟関係のほかに，株式の持ち合いや子会社 · グループ会社といった資本的な関係, 取引関係, 役員派 遣などの人的な関係 , 競合関係などがある . 本論文で取 り上げたのは, 新製品開発やサービス提供開発における 業務上の連携と, 事業統合, 営業䜇渡, 合併・買収など の資本的な関係，および, 訴訟・係争関係であり，これら 


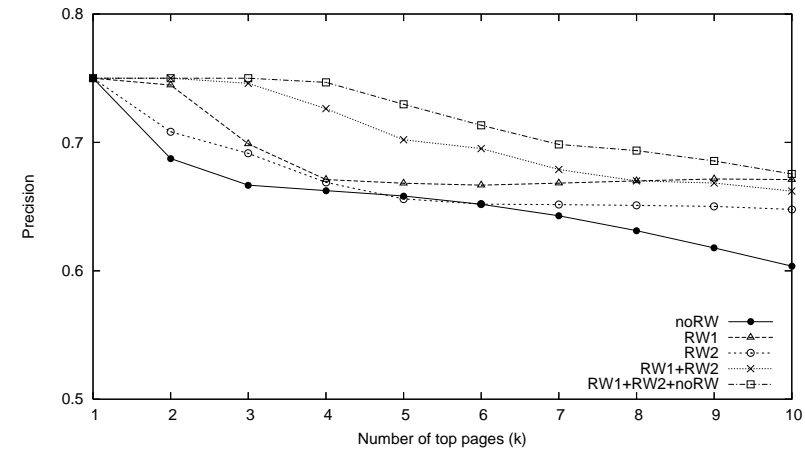

(a) 関係ページの適合率

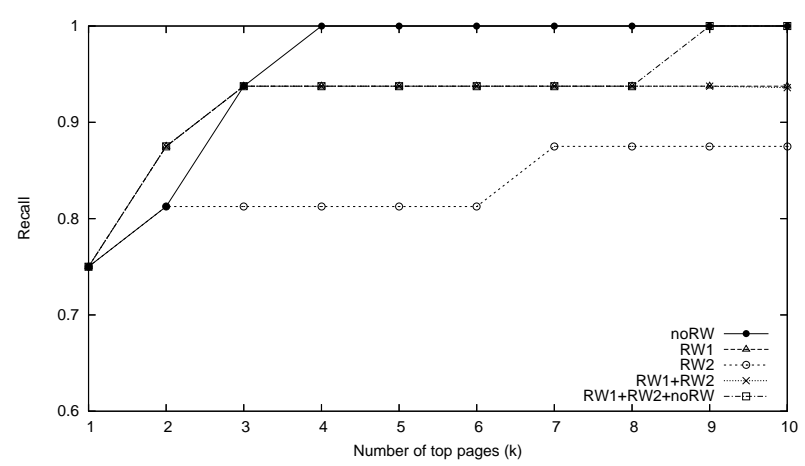

(b) 関係のカバレージ

図 6 訴訟関係の関係語の評価

はニュースとして報道されることが多いため抽出が可能 である . 他にも , 競合関係は製品の比較サイトなどで分 かるかもしれないが , 本論文とは異なるアルゴリズムに なるだろう.取引関係や資本関係，人的な関係は，Web に書かれていることもあるが，乥うでないことも多いと 予想されるので, 本研究では取り上げなかった .

本論文で取り上げなかった関係についても，どの程度 Web から抽出可能であるか , 今後アルゴリズムの拡張を 行っていきたいと考えている．具体的には，より多樣な 企業間の関係のページをヒットさせるための検索クエリ を ORやNOT 等の条件も加えながら探索的に見つけて いく手法の構築，さらに収集されたページから企業間の 関係の有無をより正確に判断するために文の係り受け解 析や意味解析と組み合わせていくこと，表形式のページ に対応することなどが考えられる．

\section{$6 \cdot 3$ 関 連 研 究}

社会ネットワークは, セマンティック Web における 情報の信頼性の計算 [Golbeck 05, Massa 05] , クチコミ マーケティングの分析 [Leskovec 05] , 情報の共有・推薦 [Mori 05b, Ghita 05] , コミュニティ抽出 [Newman 04]， オントロジー抽出 $[$ Mika 05b] など, 近年多くの研究で着 目されている .

Referral Web[Kautz 97a, Kautz 97b] では , 2 人の人 間関係の強さを，Web 上における 2 人の氏名の共起頻度 の強さによって計算している. Mika らが開発した Flink というシステム [Mika 05a] では , Email , FOAF，書誌 情報およびWeb 全体から関係情報を調べ，社会ネット ワークを視覚化している、松尾らは,POLYPHONET と いうシステムを開発し,研究者のネットワークを用いて学 会等でのコミュニケーション支援に用いている [Matsuo 06b, Matsuo 06a] .これらの研究では研究者か㳔象になつ ており，検索ヒット件数を光のまま用いてもある程度有 効であるが，企業の場合は Web 上のメディア効果という べき現象か湿著で, 注目される関係と光うでない関係の 差が激しい．したがって，より詳細に企業間にどういっ た関係があるかを同定し，個々の関係を総体的にみて紐
帯の強さを測ることが必要であろう. 本研究は, このよ うな方向に向けたひとつのアプローチを示している．

クエリにどういった語を加えればよいかについては， [Oyama 04] らの研究がある . 特定領域の情報だけを検 索するために，あらかじめ弚の領域特定の検索語（キー ワードスパイスと呼ばれる) を学習しておいて, 入力さ

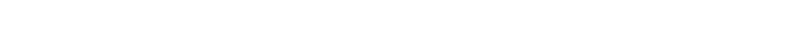
ン限定の検索を可能にする .キーワードスパイスは学習 用のページを集め，決定木を用いて学習する．Mika ら の Flink システムでは名前のあいまいさを解消するため に, S Semantic Web OR ontology」というキーワードを クエリに加えている. Bollegara らの研究 [Bollegara 06] はこのキーワードを自動で獲得するため, 氏名で検索し てヒットされる上位のページをクラスタリングすること で, 同姓同名の問題を解決している.

企業のネットワークを抽出して分析する研究にはさま ざまな研究がある，例えば，稲岡らは金融機関の振替に よる決済記録から資金取引ネットワークを抽出して，金 融システムの安定性や特徵を分析している [稲岡 03] . 相 馬らは大株主データを用いて, 上場企業もしくは店頭登 録企業に関して，日本の株所有ネットワークの遷移と特 徵について分析している [相馬 05] . 本研究では, 手軽に アクセスできる Web 上の公開情報を用いて企業関係の ネットワークを抽出しており，企業の動きを早期に的確 に捉える分析方法としての可能性を秘めていると考えて いる. 時系列的な变化については, 今後の課題のひとつ である。

\section{7. む す び}

本稿では，Web 上の情報から企業間関係を抽出する手 法について述べた . 入力された企業リストに対して，検 索エンジンを利用して Web 中にある関係のページを収 集し，関係のネットワークを構成する．企業間の特定の 関係に絞るために，関係語と呼引語を検索クエリに加え， 目的の関係だけを抽出する．本稿では，特に訴訟と提携 という関係に焦点を当てて手法を述べたが，基本的には 企業間の多樣な関係を抽出することが可能である．今後 
は，企業間の関係を定期的に抽出することにより，業界 や地域の企業間関係の変化や動向を分析する手法につな げていきたいと考えている．

\section{$\diamond$ 参 考 文 献 $\diamond$}

[Adar 04] Adar, E., Zhang, L., Adamic, L. A., and Lukose, R. M.: Implicit Structure and the Dynamics of Blogspace, in $W W W 2004$ Workshop on the Weblogging Ecosystem: Aggregation, Analysis and Dynamics (2004)

[Bollegara 06] Bollegara, D., Matsuo, Y., and Ishizuka, M.: Extracting key phrases to disambiguate personal names on the Web, in Proc. CICLing 2006 (2006)

[Ghita 05] Ghita, S., Nejdl, W., and Paiu, R.: Semantically Rich Recommendations in Social Networks for Sharing, Exchanging and Ranking Semantic Context, in Proc. ISWC05 (2005)

[Golbeck 05] Golbeck, J. and Hendler, J.: Inferring Trust Relationships in Web-Based Social Networks, ACM Transactions on Internet Technology, Vol. 7, No. 1 (2005)

[稲岡 03] 稲岡 創, 二宮 拓人, 清水 季子, 高安 秀樹 : 金融機関の 資金取引ネットワーク, Technical Report ワーキングペーパー 2003-J-2, 日本銀行金融市場局 (2003)

[Kautz 97a] Kautz, H., Selman, B., and Shah, M.: The Hidden Web, AI magazine, Vol. 18, No. 2, pp. 27-35 (1997)

[Kautz 97b] Kautz, H., Selman, B., and Shah, M.: Referral Web: Combining Social Networks and Collaborative Filtering, Communications of the ACM, Vol. 40, No. 3, pp. 63-65 (1997)

[Leskovec 05] Leskovec, J., Adamic, L. A., and Huberman, B. A.: The Dynamics of Viral Marketing (2005), http://www.hpl.hp.com/research/idl/papers/viral/viral.pdf

[Massa 05] Massa, P. and Avesani, P.: Controversial Users demand Local Trust Metrics: an Experimental Study on Epinions.com Community, in Proc. AAAI-05 (2005)

[松尾 05] 松尾 豊, 友部博教, 橋田 浩一, 石塚満: Web 上の 情報からの人間関係ネットワークの抽出, 人工知能学会論文誌, Vol. 20, No. 1E, pp. 46-56 (2005)

[Matsuo 06a] Matsuo, Y., Hamasaki, M., Takeda, H., Mori, J., Bollegala, D., Nakamura, Y., Nishimura, T., Hasida, K., and Ishizuka, M.: Spinning Multiple Social Networks for Semantic Web, in Proc. AAAI-06 (2006)

[Matsuo 06b] Matsuo, Y., Mori, J., Hamasaki, M., Takeda, H., Nishimura, T., Hasida, K., and Ishizuka, M.: POLYPHONET: An advanced social network extraction system, in Proc. $W W W 2006$ (2006)

[Mika 05a] Mika, P.: Flink: Semantic Web Technology for the Extraction and Analysis of Social Networks, Journal of Web Semantics, Vol. 3, No. 2 (2005)

[Mika 05b] Mika, P.: Ontologies are us: A unified model of social networks and semantics, in Proc. ISWC2005 (2005)

[森 05a] 森純一郎, 松尾 豊, 石塚満 : Web からの人物に関す るキーワード抽出, 人工知能学会論文誌, Vol. 20 , No. 5 , pp. 337-345 (2005)

[Mori 05b] Mori, J., Ishizuka, M., Sugiyama, T., and Matsuo, Y.: Real-world Oriented Information Sharing Using Social Networks, in Proc. ACM GROUP'05 (2005)

[Newman 04] Newman, M. E. J. and Girvan, M.: Finding and evaluating community structure in networks, Physical Review E, Vol. 69, p. 026113 (2004)

[Oyama 04] Oyama, S., Kokubo, T., and Ishida, T.: Domain-Specific Web Search with Keyword Spices, IEEE TKDE, Vol. 16, No. 1, pp. 17-27 (2004)

[佐藤 01] 佐藤 理史 : ワールドワイドウェブを利用した住所探索, 情報処理学会論文誌, Vol. 42, No. 1, pp. 59-67 (2001)

[Scott 00] Scott, J.: Social Network Analysis: A Handbook (2nd ed.), SAGE publications (2000)

[相馬 05] 相馬 亘:経済における複雑系ネットワーク一日本の経済 ネットワークは特殊か? -, 人工知能学会誌特集, Vol. 20, No. 3, pp. 289-295 (2005)

[立石 04] 立石 健二, 石黑 義, 福島 俊一: インターネットからの 評判情報検索, 人工知能学会学会誌, Vol. 19, No. 3 (2004)

[安田 97] 安田 雪: 社会ネットワーク分析一何が行為を決定する か一, 新曜社 (1997)

[金光 03] 金光 淳 : 社会ネットワーク分析の基礎 -社会的関係資 本論にむけて一, 勁草書店 $(2003)$

[坂田 05] 坂田一郎, 柴田 尚樹, 小島 拓也, 梶川裕矢, 松島 克 守 : 地域経済圏の成長にとって最適な地域ネットワークとは一 Small-World Networks の視点による4 地域クラスターの比較 分析一, 一橋ビジネスレヴュー, Vol. 53, No. 3, pp. 182-195 (2005)

[増田 06] 増田 直紀, 今野 紀雄 : 「複雑ネットワーク」とは何か, University of Toronto (2006)

[湯田 05] 湯田 聴夫, 藤原 義久：SNS における人のネットワー ク構造〜关の地平線の超え方〜, Web が生み出す関係構造と社 会ネットワーク分析ワークショップ (2005)

[藤井 04] 藤井 敦 : 百科事典としてのWWW, 人工知能学会誌, Vol. 19, No. 3, pp. 296-301 (2004)

〔担当委員：伊藤 公人〕

2006 年 6 月 3 日 受理

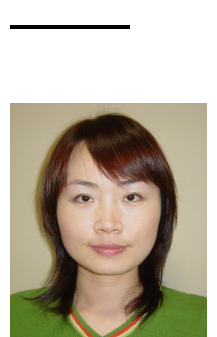

\section{者 紹}

\section{金英子(正会員)}

2001 年 (中国上海) 華東師範大学物理学部卒業. 同年滕 龍計算機軟件 (上海) 有限公司入社. 2006 年東京大学大 学院情報理工学系研究科修士課程終了. 現在, 同大学院博 士課程在学中. Web マイニング, 言語処理等に興味があ る. 言語処理学会会員

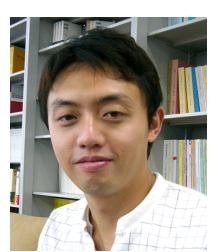

\section{松尾＼cjkstart豊(正会員)}

1997 年 東京大学工学部電子情報工学科卒業. 2002 年 同 大学院博士課程修了。博士 (工学) . 同年より, 産業技術総 合研究所 情報技術研究部門勤務, 2005 年 10 月よりス タンフォード大学客員研究員 . 人工知能、特に高次 $\mathrm{Web}$ マイニングに興味がある.人工知能学会、情報処理学会、 AAAI の各会員

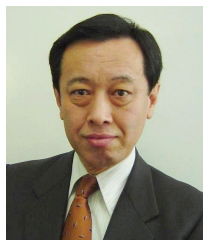

\section{石塚 満(正会員)}

1971 年東京大学工学部電子卒, 1976 年同大学院博士修 了. 工博. 同年 NTT 入社，横須賀研究所勤務. 1978 年 東大大学生産技術研究所・助教授, (1980-81 年 Purdue 大学客員準教授)，1992 年東京大学工工学部電子情報・教 授，2001 年情報理工学系研究科・電子情報学専攻，2005 年同創造情報学専攻 (電子情報学専攻兼任) . 研究分野は 人工知能, Web インテリジェンス, 次世代 Web 情報基 盤，生命的エージェントによるマルチモーダルメディア IEEE, AAAI, 情報処理学会, 電子情報通信学会, 映像情報メディア学会, 画 像電子学会, 等の会員. 